\title{
Apis cerana F. as an Important Natural Pollinator of Radish (Raphanus sativus L.) under Mid-hill Conditions of Himachal Pradesh
}

\author{
Harish Kumar Sharma, Sapna Katna*, B. S. Rana and Kiran Rana
}

Dept. of Entomology, Dr Y S Parmar University of Horticulture \& Forestry, Nauni, Solan, Himachal Pradesh (173 230), India

\section{Article History}

Manuscript No. AR1526

Received in $16^{\text {th }}$ January, 2016

Received in revised form $4^{\text {th }}$ October, 2016

Accepted in final form $7^{\text {th }}$ October, 2016

\section{Correspondence to}

*E-mail: sapnakatna@rediffmail.com

\section{Keywords}

Apis cerana, A. mellifera, radish, pollination efficiency, seed quality

\begin{abstract}
The present studies were undertaken to find out the pollination efficiency of Apis mellifera L. and other natural pollinators in radish (cv. Pusa Himani) and their impact on yield and quality of seeds under mid hill conditions of Himachal Pradesh. A. cerana was dominant amongst all insect visitors being 5.85 and 6.6 bees $\mathrm{m}^{-2} 5$ minutes ${ }^{-1}$ in 2011 and 2012, respectively. A. mellifera (introduced bee species) population was quite low (0.3) during 2011 which clearly indicated that the bees did not get conditioned to the target crop. Pollination index showed that $A$. cerana scored maximum i.e. 13.63 and 15.38 in 2011 and 2012, respectively. Pod set recorded during 2011 and 2012 in radish did not vary significantly at different distances from the $A$. mellifera colonies. The values being $34.42,28.55,30.9$ and $29.3 \%$ respectively at $25 \mathrm{~m}, 50 \mathrm{~m}, 75 \mathrm{~m}$ and $100 \mathrm{~m}$ distance in 2011. The respective values during 2012 were 28.17, 27.09, 25.81 and $22.73 \%$. During 2012, the parameters of seed quality like pod set, seed number and seed weight showed decreasing trend with increase in the distance from the placement of $A$. mellifera colony. This could be due to comparatively more activity of $A$. mellifera on radish bloom during this year. The present studies suggest that $A$. cerana along with other natural pollinators are providing natural pollination services for pollination of radish and other crops. Hence there is urgent need to devise suitable strategies for the conservation of these pollinators.
\end{abstract}

\section{Introduction}

Availability of the desired quantity of quality seed is one of the most important aspects for a successful vegetable industry. For the production of such quality seeds, sufficient or adequate cross-pollination of vegetable crops is essential. Further, many of the vegetable crops are completely or partly incompatible and incapable of pollinating themselves. Cross-pollination by honey bees is, therefore very important. Vegetable flowers in return are excellent sources of pollen and nectar to bees (Atwal, 2000; Abrol, 2010).

Radish (Raphanus sativus L.) is an important root vegetable crop, used as salad as well as cooked vegetable. It has good nutritional and medicinal value. Most commercial cultivars of radish, are self incompatible (Crane and Marther, 1943). Self incompatibility in radish necessitates the services of insect pollinators for efficient pollination and increased seed set. The effect of insect pollination on seed production has been reported by Prasad et al. (1989), Singh and Chamotre (1992), Verma and Phogat (1994); Kapila et al. (2002); Sharma et al. (2010).
In addition, the effectiveness of honey bees as pollinators of radish bloom has also been studied by different workers (Uma and Verma, 1994; Verma and Phogat, 1994; Sattigi et al., 1996; Shivaramu and Chittiraicheluam, 2002; Chandrashekhar and Sattigi, 2006). Sometimes crops like radish are ignored by pollinators when more attractive flowers are available in the vicinity of the area. Thus, pollination and, therefore seed set in the less attractive crops is adversely affected. Therefore, the present studies were undertaken to find out the pollination efficiency of Apis mellifera L. and other natural pollinators in radish (cv. Pusa Himani) and their impact on yield and quality of seeds under mid-hill conditions of Himachal Pradesh.

\section{Materials and Methods}

The present investigations were carried out at farm of Department of Seed Technology and Production of Dr. Y.S. Parmar University of Horticulture and Forestry, Nauni, Solan during the years 2011 and 2012 in the month of March at an elevation of 987 masl. One colony of $A$. mellifera having 8 frames bee strength was kept in the radish field at the time 
of $10 \%$ bloom during both the years. However, in 2012 an attempt has been made to condition $A$. mellifera to the target crop (radish) by feeding 50\% sugar solution having scent of radish flowers at night or early in the morning before the bees go out for foraging. The scented sugar syrup was prepared by soaking the radish flowers in sugar syrup $(50 \%)$ and kept for few hours. Then the syrup was poured in the feeder and fed to the bees.

Data on various parameters like relative abundance of insect visitors, foraging rate, foraging speed, loose pollen grains, per cent pod set, number of seeds pod ${ }^{-1}$ and weight of 100 dry seeds were recorded. Counts of insects visiting the radish bloom 5 minutes ${ }^{-1} \mathrm{~m}^{-2}$ were made daily for three consecutive sunny days during peak activity period i.e. $1000 \mathrm{~h}$ to $1200 \mathrm{~h}$. Foraging speed of pollinators on the bloom was recorded by observing time spent by the forager on each flower using stop watch. Foraging rate was recorded in term of number of flowers visited by a forager minute ${ }^{-1}$. Number of loose pollen grains adhering to the body of bees was determined by capturing the forager and killing immediately in $5 \mathrm{ml}$ of $70 \%$ alcohol in glass vials. From the rinsate an aliquot of $0.02 \mathrm{ml}$ (replicated three times), was taken on a counting dish and the pollen grains were counted under binocular microscope at $100 \times$ magnification. Total number of pollen grains in the whole rinsate was then calculated.

Pollination efficiency of pollinators was assessed on the basis of their relative abundance and foraging behavior, such as foraging rate, foraging speed, number of loose pollen grains sticking to their bodies. In order to have fair assessment of relative efficiency, ratings were assigned. The ranks were assigned on the basis of statistical analysis of the data. Different scores were given to the values which differed significantly. Average efficiency ratings thus obtained were multiplied by the mean population of each pollinators (average number of bees $\mathrm{m}^{-2} 5$ minutes $^{-1}$ ) during a day in order to obtain the pollination indices (PI) as suggested by Bohart and Nye (1960) for most predominant visitors which included $A$. cerana, A. mellifera and Episyrphus balteatus.

\section{Results and Discussion}

\subsection{Relative abundance of insect visitors}

The data on relative abundance (number $\mathrm{m}^{-2} 5$ minutes $^{-1}$ ) recorded for three sunny days revealed that $A$. cerana was dominant amongst all insect visitors being 5.85 and 6.6 bees $\mathrm{m}^{-2}$ 5 minutes $^{-1}$ in 2011 and 2012, respectively. Our observations further revealed that $A$. mellifera (introduced bee species) population was quite low (0.3) during 2011 which clearly indicated that the bees did not get conditioned to the target crop.

The data on bee activity recorded during both the years showed that activity of $A$. cerana was significantly higher and their proportion being 50 and $58 \%$ for the respective years, which clearly indicate that indigenous honey bee is playing an major role of natural pollination specially when introduced A. mellifera was preferring other competing flora like sarson, rudillo, berberris and coriander blooming in the vicinity, activity being 5.0, 6.0, 2.0 and 2.0 bees $\mathrm{m}^{-2}$ 5 minutes $^{-1}$, respectively. Honey bees have been reported to neglect radish for other competing crops which secrete nectar more abundantly (Kremer, 1945; Uma et al., 1998). The data further revealed that the proportion of introduced A. mellifera increased from 3 to $19 \%$ by conditioning A. mellifera by feeding scented sugar syrup having scent of radish flowers. These results suggest that few $A$. mellifera foragers shifted to radish bloom from competing flora when fed on scented sugar syrup. Sharma (2012) reported a general trend of increase in bee activity at $50 \mathrm{~m}$ by feeding scented sugar syrup with scent of apple flowers. Free (1958) was unable to guide bees by scent to apple flowers and red clover. Possible reasons cited were conditions being unfavourable due to strong competition from other sources of food.

Other important pollinator group of radish under mid hill conditions comprises of syrphids. However, syrphids are not dependent pollinators since there population vary greatly from year to year being $4.63 \mathrm{~m}^{-2} 5$ minutes $^{-1}$ during 2011 and 1.2 in 2012. Insect visitors like lepidopterans, other dipterans were also found visiting radish bloom but their activity was quite poor. Many workers (Muhammad et al., 1973; Sihag, 1986; Verma and Poghat, 1994; Bhatia et al., 1999; Priti et al., 2001; Chandrashekhar and Sattigi, 2006; Sharma et al., 2010) have recorded that hive bees were more frequent visitors on radish bloom than syrphids and lepidopterans.

In our present studies, both the hive bees showed different preferences for the available bloom in the location where target crop (radish) is growing indicating that A. cerana is more reliable pollinator under such conditions. Sharma et al. (1998) have also reported resource partitioning among hive bees. But from pollination point of view, A. cerana visits radish flower which produces least amount of nectar with lowest sugar concentration and is least attractive to bees and other pollinating insects (Uma et al., 1998). Whereas A. mellifera preferred competing flora growing in the vicinity.

In our present studies, both the hive bees showed different preferences for the available bloom in the location where target crop (radish) is growing indicating that A.cerana is more reliable pollinator under such conditions. Sharma et al. (1998) have also reported resource partitioning among hive bees. But from pollination point of view, A. cerana visits radish flower which produces least amount of nectar with lowest 


\begin{tabular}{|c|c|c|c|c|c|c|c|c|}
\hline \multirow{3}{*}{$\begin{array}{l}\text { Insect } \\
\text { pollinators }\end{array}$} & \multicolumn{8}{|c|}{ Foraging behaviour } \\
\hline & \multicolumn{4}{|c|}{2011} & \multicolumn{4}{|c|}{2012} \\
\hline & $\begin{array}{l}\text { Foraging } \\
\text { rate (number } \\
\text { of flowers } \\
\text { visited / } \\
\text { minute) }\end{array}$ & $\begin{array}{l}\text { Foraging } \\
\text { speed } \\
\text { (time } \\
\text { spent on a } \\
\text { flower in } \\
\text { seconds) }\end{array}$ & $\begin{array}{c}\text { Loose } \\
\text { pollen } \\
\text { grain } \\
\text { (no.) }\end{array}$ & $\begin{array}{l}\text { Pollination } \\
\text { index (PI) }\end{array}$ & $\begin{array}{c}\text { Foraging rate } \\
\text { (number } \\
\text { of flowers } \\
\text { visited / } \\
\text { minute) }\end{array}$ & $\begin{array}{l}\text { Foraging } \\
\text { speed } \\
\text { (time spent } \\
\text { on a flower } \\
\text { in seconds) }\end{array}$ & $\begin{array}{l}\text { Loose } \\
\text { pollen } \\
\text { grain } \\
\text { (no.) }\end{array}$ & $\begin{array}{l}\text { Pollination } \\
\text { index }\end{array}$ \\
\hline A. mellifera & 5.25 & 8.00 & 1550 & 0.80 & 8.00 & 5.00 & 1525 & 5.85 \\
\hline A. cerana & 7.12 & 7.60 & 1062 & 13.63 & 8.20 & 5.60 & 1100 & 15.38 \\
\hline E. balteatus & 1.50 & 32.30 & 141 & 4.63 & 1.80 & 28.20 & 125 & 1.20 \\
\hline $\mathrm{CD}(p=0.05)$ & 1.66 & 11.21 & 95.08 & & 1.29 & 2.66 & 38.81 & \\
\hline
\end{tabular}

sugar concentration and is least attractive to bees and other pollinating insects (Uma et al., 1998). Whereas A. mellifera preferred competing flora growing in the vicinity.

\subsection{Foraging behaviour}

Foraging behaviour with respect to foraging rate, foraging speed and loose pollen grain adhered to the body of hive bees and Episyrphus balteatus were recorded (Table 1). Maximum number of flowers were visited by A. cerana ( 7.12 and $8.2 /$ minutes in 2011 and 2012, respectively) followed by $A$. mellifera (5.25 and 8.0) and syrphids (1.5 and 1.8). A. cerana was found to spend 7.6 and 5.6 secper flower (foraging speed) during 2011 and 2012, respectively. Respective values for $A$. mellifera were 8.0 and $5.0 \mathrm{sec}$. These findings are in line with the report of Uma and Verma (1994) who reported average foraging rate and speed of $A$. cerana to be 7.3 minutes $^{-1}$ and 7.46 seconds flower ${ }^{-1}$, respectively on radish.

Maximum time was spent by syrphids being 32.30 and $28.2 \mathrm{sec} /$ flower during 2011 and 2012, respectively. The data recorded in both the years on loose pollen grains on the body of bees revealed that more number of average loose pollen grains were adhered to the body of $A$. mellifera (1550 and 1525) than $A$. cerana (1062 and 1100) and syrphids (141 and 125).
Data on pollination index (Table 1) showed that A. cerana scored maximum during both the years (13.63 and 15.38). No information on pollination index on this crop have been found in the literature. However, Sharma and Gupta (1993) have recorded maximum pollination index of $A$. cerana on apple and almond under mid hill conditions. The pollination index values for A. mellifera were 0.80 and 5.85 during 2011 and 2012, respectively. The low value of PI in 2011 was due to poor activity of $A$. mellifera on radish since the values with respect to foraging rate, foraging speed and loose pollen grain was highest for this bee during both the years. On the basis of foraging rate, foraging speed, loose pollen grains and relative abundance of pollinators A. cerana is rated as most efficient pollinator among the prevalent pollinators in the radish.

\subsection{Seed set and seed quality}

Pod set recorded during 2011 and 2012 in radish did not vary significantly at different distances from the $A$. mellifera colonies. The values being $34.42,28.55,30.9$ and $29.3 \%$ respectively at $25 \mathrm{~m}, 50 \mathrm{~m}, 75 \mathrm{~m}$ and $100 \mathrm{~m}$ distance in 2011 . The respective values during 2012 were 28.17, 27.09, 25.81 and $22.73 \%$. There was no pod set in control plants which were covered with muslin bags prior to flowering. The average

Table 2: Impact of placement of A. mellifera colonies on seed quality in Raphanus sativus L. during 2011 and 2012

\begin{tabular}{|c|c|c|c|c|c|c|c|c|}
\hline \multirow{3}{*}{$\begin{array}{l}\text { Distance } \\
\text { from bee } \\
\text { colony } \\
\text { (m) }\end{array}$} & \multicolumn{8}{|c|}{ Seed quality } \\
\hline & \multicolumn{4}{|c|}{2011} & \multicolumn{4}{|c|}{2012} \\
\hline & $\begin{array}{c}\text { Pod set } \\
(\%)\end{array}$ & $\begin{array}{l}\text { Seeds } \\
\text { pod }^{-1} \\
\text { (no.) }\end{array}$ & $\begin{array}{c}\text { Weight of } \\
100 \text { seeds } \\
(\mathrm{mg})\end{array}$ & $\begin{array}{c}\text { Seed } \\
\text { germination } \\
(\%)\end{array}$ & $\begin{array}{c}\text { Pod set } \\
(\%)\end{array}$ & $\begin{array}{l}\text { Seeds } \\
\text { pod }^{-1} \\
\text { (no.) }\end{array}$ & $\begin{array}{c}\text { Weight of } \\
100 \text { seeds } \\
(\mathrm{mg})\end{array}$ & $\begin{array}{c}\text { Seed } \\
\text { germination } \\
(\%)\end{array}$ \\
\hline 25 & 34.42 & 6.2 & 1680 & 100 & 28.17 & 5.8 & 1480 & 90 \\
\hline 50 & 28.55 & 5.7 & 1540 & 100 & 27.09 & 5.5 & 1423 & 90 \\
\hline 75 & 30.90 & 5.2 & 1440 & 100 & 25.81 & 4.6 & 1251 & 89 \\
\hline 100 & 29.30 & 4.5 & 1640 & 100 & 22.73 & 4.2 & 1134 & 92 \\
\hline $\mathrm{CD}(p=0.05)$ & NS & 0.6 & 41.24 & NS & NS & 0.26 & 165 & NS \\
\hline
\end{tabular}


number of seeds counted pod $^{-1}$ showed variation at different distances. During 2011, the seeds pods ${ }^{-1}$ were maximum (6.2) at $25 \mathrm{~m}$ distance from the colony which was statistically at par to the number of seeds obtained at $50 \mathrm{~m}$ (5.7). Lowest number of seeds (4.5) were recorded at $100 \mathrm{~m}$ distance. During 2012, the seeds pods ${ }^{-1}$ were statistically different at all the distances (5.8 at $25 \mathrm{~m}$ and 4.2 at $100 \mathrm{~m}$ ). Weight of 100 dried seeds did not showed any trend during 2011 being 1680, 1540, 1440 and $1640 \mathrm{mg}$ at 25, 50, 75 and $100 \mathrm{~m}$, respectively. However, during 2012 the seed weight was significantly more at 25 and $50 \mathrm{~m}$ distances (1480 and $1423 \mathrm{mg}$ ), being statistically same. The weight of the seeds produced at $75 \mathrm{~m}$ and $100 \mathrm{~m}$ was comparatively low (1251 and $1134 \mathrm{mg}$ ) which was statistically at par. The per cent seed germination was $100 \%$ at all the distances in 2011 whereas during 2012 seed germination varies non-significantly between $89-92 \%$ at all the distances. In general, during 2012, the parameters of seed quality like pod set, seed number and seed weight showed decreasing trend with increase in the distance from the placement of $A$. mellifera colony. This could be due to comparatively more activity of $A$. mellifera on radish bloom during this year. Uma and Verma (1994) have reported 51.2\% pod set, 5.2 seeds pod $^{-1}, 1276 \mathrm{mg}$ 100 seed weight and $44 \%$ germination rate in radish crop in Kathmandu, Nepal. Priti et al. (2001) reported that fruit set was 81 and $56.55 \%$, number of seeds pod ${ }^{-1}$ was 8.6 and 4.8 and seed weight 1.5 and 0.9 grams in bee pollinated and self pollinated radish, respectively. Kapila et al. (2002) have also reported that open pollinated plants of radish had greater number of grains siliqua $^{-1}, 100$ seed weight and seed set than the caged plants, indicating the positive effects of insect pollination on seed production and quality. The variation in seed set and quality could be due to different varieties and experimental conditions.

\section{Conclusion}

A. cerana along with other natural pollinators are providing natural pollination services for pollination of radish and other crops. Hence there is urgent need to devise suitable strategies for the conservation of these pollinators. Further honey bees can be conditioned to the less preferred target crop like radish for increasing their activity on such crops.

\section{Acknowledgement}

The authors are thankful to all India coordinated research project on honey bees and pollinators, Indian Council of Agricultural Research, New Delhi for providing financial assistance.

\section{References}

Abrol, D.P., 2010. Beekeeping-A Comprehensive Guide on Bees and Beekeeping, Scientific Publishers, Jodhpur,
896.

Atwal, A.S., 2000. Essentials of Beekeeping and Pollination. Kalyani Pulishers, New Delhi, 393.

Bhatia, R., Koul, B.L., Sharma, A.K., 1999. Pollinator fauna of carrot (Daucus carota L.) and radish (Raphanus sativus L.) in foot hills of Himachal Pradesh and its role in fruit set. Journal of Hill Research, 12(2), 154-156.

Bohrat, G.E., Nye, W.P., 1960. Insect pollination of carrots in Utah. Bulletin of Utah Agriculture Express Station 480, 145.

Chandrashekhar, G.S., Sattigi, H.N., 2006. Pollinator fauna and foraging activity of bees and other pollinators in radish. Karnataka Journal of Agricultural Sciences 19(3), 719-721.

Crane, M.B., Mather, K., 1943. The natural cross-pollination of crop plants with particular reference to the radish. Annals of Applied Biology 30, 301-308.

Free, J.B., 1958. Attempts to condition bee to visit selected crops. Bee World 39, 221-230.

Kapila, R.K., Singh, H.B., Sharma, J.K, Lata, S., Thakur, S.P., 2002. Effect of insect pollinators on seed yield and its quality in radish (Raphanus sativus L.). Seed Research 30(1), 142-145.

Kermer, J.C., 1945. Influence of honeybees habits on radish seed yield. Michigan Agricultural Experimental Station Quarterly Bulletin 27, 413-428.

Muhammad, S., Gondal, A., Manzoor-Ul-Haq., 1973. Studies on the role of Apisindica F. in the pollination of cauliflower (Brassica oleracea var. botrytis Linn.) and radish (Raphanus sativus Linn.) Sind University Research Journal (Science Series) 7(1/2), 87-93.

Prasad, D., Hameed, S.F., Singh, R., Yazdani, S.S., Singh, B., 1989. Effect of bee pollination on the quantity and quality of Rai crop (Brassica juncea coss.). Indian Bee Journal 5(12), 45-47.

Mishra, Priti, R.C., Sihag, R.C., 2001. Role of insect pollination in seed production of radish (Raphanus sativus L.). Seed Research, 29(2), 231-234.

Sattigi, H.K., Lingappa, S., Kulkarnim, K.A., 1996. Seasonal variation of foraging behavior of Indian bee, Apis cerana Fab. Karnataka Journal of Agricultural Sciences 1, 43-48.

Sharma, H.K., Gupta, J.K., 1993. Pollination efficiency of Apis cerana indica $\mathrm{F}$. and Apis mellifera L. on some important crops of Himachal Pradesh. In: International Symposium on Pollination in Tropics, Bangalore, India, 203-204.

Sharma, H.K., Gupta, J.K., Rana, B.S., 1998. Resource partitioning among Apis mellifera and Apis cerana under mid-hill conditions of Himachal Pradesh. In: $4^{\text {th }}$ Asian Apicultural Association International Conference, Kathmandu, 213-215. 
Sharma, H.K., Rana, K., Rana, B.S., Shukla, Y.R., 2010. Studies on the use of honey bees for breeder seed production in radish. In: National symposium on perspectives and challenges of integrated pest management for sustainable agriculture, Solan Himachal Pradesh, India, 77.

Sharma, R., 2012. Investigations on the pollinator fauna in selected eco-environmental conditions of Himachal Pradesh and promoting pollinator husbandry. Ph.D Thesis Submitted to Dr Y.S. Parmar University of Horticulture \& Forestry, Nauni, Solan, H.P. (173 230), 127.

Shivaramu, K., Chithiraicheluam, R., 2002. Role of honeybees in pollination of radish (Raphanus sativus) for higher seed production. In: $6^{\text {th }}$ Asian Apicultural Association. International Conference, Bangalore, India, 72.

Sihag, R.C., 1986. Insect pollination increases seed production in cruciferous and umbelliferous crops. Journal of
Apicultural Research, 25, 121-126.

Singh, A.K., Chamotre, V.K., 1992. Seed setting under different system of pollination in radish. Vegetable Science 19(2), 217-220.

Uma, Pratap, Shukla, A.N., Verma, L.R., 1998. Comparative attractiveness of broad leaf mustard, cauliflower and radish to Apis cerana in the Kathmandu valley of Nepal. In: $4^{\text {th }}$ Asian Apicultural Association International Conference, Kathmandu, 203-205.

Uma, Pratap, Verma, L.R., 1994. Pollination of radish by Apis cerana. Journal of Apicultural Research, 33(4), 237-241.

Verma, S.K., Phogat, K.P.S., 1994. Impact of pollination by honeybees (Apis cerana) on yield of radish under caged condition of Himalayan hills. Indian Bee Journal 45, 183-186. 